\title{
Metodologi Tafsir Al-Quran Secara Al-Ishārah: Suatu Penilaian Hukum
}

\author{
Oleh: \\ Rushdi Ramli*
}

\section{PENDAHULUAN}

Al-Quran adalah sebuah kitab yang diturunkan dari sisi Allah, untuk membimbing manusia, ke jalan yang diredai Allah, sebagaimana yang dijelaskan di dalam al-Quran:

"Sesungguhnya al-Quran ini benar-benar memberi pertunjuk ke jalan yang paling lurus."

Surah al-Isrā' (17): 9

Peranan dan kedudukan al-Quran sebagai pembimbing dan petunjuk kepada manusia sudah pastinya tidak akan tercapai sekiranya segala isi kandungannya, yang tersurat dan yang tersirat, tidak dapat difahami dan diselami dengan baik oleh manusia, khususnya oleh umat Islam itu sendiri. Malah galakan agar setiap Muslim merenungi, memikir dan memerhatikan maksud dan pengertian setiap ayat-ayat al-Quran telah diperintahkan secara jelas melalui firman Allah yang bermaksud:

"Apakah mereka tidak memerhatikan serta memikirkan isi kandungan al-Quran...."

Surah Muhammad (47): 24

Kerana itu sejak dari awal perkembangan Islam, bermula dari era Nabi Muhammad saw sendiri dan disusuli dengan era para Sahabat Nabi SAW, ilmu yang bertujuan untuk menjelaskan segala

\footnotetext{
* Pensyarah Kanan, Jabatan Fiqh \& Usul, Akademi Pengajian Islam, Universiti Malaya, Kuala Lumpur.
} 
maksud dan makna yang terkandung di dalam al-Quran, yang kemudiannya diistilahkan sebagai ilmu tafsir, telah berkembang dengan pesat dan terus berkembang sehingga ke hari ini.

Sejak dari awal-awal lagi dan di dalam setiap masa dan ketika kita melihat bagaimana para ulama Islam telah mencurahkan segala tenaga dan minda mereka bagi mengungkapkan serta memperjelaskan segala maksud dan pengertian yang dapat difahami dari ayat-ayat al-Quran sehingga lahirnya pelbagai karya tafsir yang amat bernilai, yang dapat ditatapi dan diambil manfaatnya oleh generasi umat Islam sejak dari dahulu sehingga kini. Begitu juga dalam konteks perkembangan ilmu tafsir itu sendiri kita melihat bagaimana para ulama telah mencurahkan segala daya usaha mereka untuk cuba memperjelaskan maksud dan pengertian al-Quran dengan melihat kepada hampir kesemua aspek dan dari semua sudut yang berkaitan dengan al-Quran.

Kerana itu kita mendapati terdapat karya tafsir yang memberikan tumpuan yang khusus terhadap aspek hukum-hakam yang terdapat di dalam ayat-ayat al-Quran, terdapat karya tafsir yang memberikan tumpuan terhadap riwayat-riwayat tafsir yang sahih, yang dinaqal serta diriwayatkan dari generasi terawal umat Islam, yang kemudiannya pendekatan tafsir ini diistilahkan dengan ungkapan tafsìr bi al-ma 'thūr. Dan begitu juga terdapat karya tafsir tafsir yang cuba mengenengahkan segala pengertian, maksud dan 'ibrah al-Quran [pengajaran ayat] melalui ijtihad, kekuatan minda dan instrumen bahasa Arab itu sendiri, yang diistilahkan dengan ungkapan tafsìr bi al- 'aql atau tafsìr bi al-ra'y wa al-ijtihād.

Selain dari aspek dan sudut yang dinyatakan di atas kita juga mendapati terdapat beberapa karya tafsir tersohor yang, selain dari mengenengahkan maksud al-Quran menurut pendekatannya yang lazim iaitu dengan melihat kepada makna zahir sesuatu ayat, turut merangkumkan tafsiran-tafsiran al-Quran yang difahami secara tersirat dan isyarat. Inilah bentuk tafsir yang diistilah oleh para ulama dengan ungkapan al-tafsìir al-Isyārí.

\section{PENGERTIAN TAFSIR SECARA $A L-I S H \bar{A} R A H$}

Menurut penjelasan Muhammad 'Abd al-'Ażīm al-Zarqāní, tafsir secara al-ishārah ini merujuk kepada usaha mentafsirkan 
makna al-Quran, tidak berdasarkan lafaz-lafaz al-Quran yang dapat difahami secara zahir dan biasa menurut bahasa Arab, tetapi berasaskan kepada isyarat-isyarat yang tersirat [ishärah khafiyyah] yang terzahir [yakni, yang dizahirkan oleh Allah] kepada para ahli suluk dan para ahli tasawuf di mana pengertian-pengertian secara al-ishärah ini itu masih boleh diharmonikan serta dihubungkaitkan dengan tafsiran secara yang "tersurat". ${ }^{1}$ Manakala Khālid 'Abd al-Raḥmān al- 'Akk pula menyatakan bahawa al-tafsìr al-ishāri diertikan sebagai mentafsirkan ayat-ayat al-Quran, bukannya berdasarkan apa yang zahirr, nyata dan "tersurat" dari lafaz-lafaz al-Quran, iaitu bukannya berdasarkan apa yang dapat difahami secara nyata melalui instrumen bahasa Arab yang standard atau kaedah-kaedah usul tafsir yang telah diterima-pakai, tetapi berdasarkan isyarat-isyarat yang tersirat atau petunjuk-petunjuk yang tersirat dan tersembunyi, yang tersingkap atau disingkapkan oleh Allah kepada para ahli riyā dah dan Sulūk, dan isyarat-isyarat tersirat ini juga, pada masa yang sama, terbina berasaskan kepada kesesuaian dan keharmonian yang wujud antara isyarat tersebut dengan makna-makna zahir yang dapat difahami dari sesuatu ayat al-Quran di dalam aspek-asepk yang diperakukan syarak. ${ }^{2}$

Berasaskan kepada kedua-dua takrifan yang dinyatakan ini penulis merumuskan bahawa terdapat tiga elemen utama yang berkaitan dengan tafsir secara ishārah yang muktabar iaitu :

1. Tafsiran tersebut tidak melihat atau terfokus kepada makna bahasa Arab yang diterima-pakai secara umum, iaitu berbeza dengan pendekatan tafsiran al-Quran secara umumnya yang dilakukan oleh para ulama tafsir yang muktabar di mana mereka sentiasa menekankan kepentingan bahasa Arab dan ilmu-ilmu al-Quran sebagai instrumen terpenting di dalam memahami makna al-Quran;

2. Walaupun tidak terikat dengan makna lafaz-lafaz yang zahir atau makna yang tersurat dari al-Quran tetapi ianya tidaklah pula terpisah atau dipisahkan dari lafaz yang zahir tersebut secara mutlak; sebaliknya tafsiran-tafsiran secara "isyarat"

Muḥammad 'Abd al- 'Aẓīm al-Zarqānī (1998), Manāhil al- 'Irfän Fī 'Ulūm al-Qur'ān. Beirut: Dār Ihyya' al-Turāth al- 'Arabī, h. 386.

2 Khālid 'Abd al-Raḥmān al-'Akk (1986), Ușūl al-Tafșir Wa Qawā 'iduh. Beirut: Dār al-Nafā'is, h. 205. 
yang dikemukakan itu tetap dan semestinya mempunyai kesesuaian dan keharmonian dengan makna-makna zahir ayat al-Quran tersebut; dan

3. Tafsiran-tafsiran secara isyarat tersebut merupakan pengertian-pengertian kepada ayat-ayat al-Quran yang bersifat tersirat dan tersembunyi dan merupakan ilham yang disingkapkan oleh Allah kepada para hambaNya yang memiliki kesucian jiwa yang tinggi dan murni.

\section{AUTORITI TAFSIR SECARA $A L-I S H A R A H$}

Secara umumnya terdapat ramai dari kalangan para ulama yang tidak menerima pendekatan tafsir secara al-ishārah ini sebagai salah satu metode yang muktabar dan sah bagi mentafsir ayat-ayat al-Quran. Menurut mereka, pendekatan tafsir secara al-ishārah ini akan hanya membuka ruang yang luas kepada individu-individu tertentu, terutamanya kepada para ahli suluk yang tidak memiliki ilmu agama yang cukup dan mantap, untuk menyatakan perkara-perkara yang tidak benar mengenai pengertian ayat-ayat al-Quran. Dengan bahasa lain, pendekatan tafsir secara al-ishārah ini akan mendedahkan al-Quran kepada pelbagai tafsiran yang batil, yang tidak berasaskan kepada ilmu yang hak, petunjuk dan hujah-hujah yang kukuh. ${ }^{3}$

Sebagai misalan, al-Nasāfī, salah seorang ulama tafsir yang amat tersohor dengan karya tafsirnya, menyatakan, "nas-nas alQuran perlu ditafsirkan berdasarkan makna-makna yang zahir dari lafaz-lafaznya di mana berpalingnya kita dari makna-makna yang zahir tersebut [yakni, mengingkari makna-makna yang zahir tersebut secara mutlak] kepada makna-makna yang tersirat yang didakwa oleh para ahli batil ini merupakan suatu ilhād [suatu perbuatan yang akan membawa kepada kekufuran]"4

Sebaliknya, terdapat juga segelintir para ulama muktabar yang memperakui kesahihan, kebaikan dan kebenaran apa yang diistilahkan sebagai tafsìr bi al-ishārah. Bagi mengesahkan pendirian mereka, mereka berhujah dengan ayat 24 dari surah Muhammad [maksudnya] "Apakah mereka tidak memikirkan

3 Ibid., h. 208.

$4 \quad$ Al-Zarqānì (1998), op.cit., h. 386. 
isi kandungan al-Quran atau telah ada kunci penutup di atas hati-hati mereka".

Menurut mereka ayat ini secara jelas menegaskan kepentingan memahami isi kandungan al-Quran, bukan sahaja secara yang "tersurat" yang dapat difahami melalui instrumen bahasa Arab, tetapi merangkumi makna-makan yang "tersirat" yang dapat ditelusi dan diterokai melalui penggunaan akal dan minda yang sihat dan juga melalui ilham-ilham ketuhanan yang merupakan natijah dan buah kepada hati dan jiwa nurani yang bersih dan suci dari noda-noda kekufuran dan kesyirikan. ${ }^{5}$

Golongan ini juga berhujah dengan menyatakan bahawa apabila orang-orang kafir musyrikin Arab di zaman Nabi SAW mendengar ayat-ayat al-Quran, adalah jelas bahawa mereka berupaya memahami maksud-maksud yang zahir dari ayat-ayat al-Quran kerana ianya diturunkan dengan bahasa ibunda mereka. Walau bagaimana pun kefahaman mereka terhadap pengertian yang zahir dari ayat-ayat al-Quran kelihatan tidak memadai dan tidak cukup sehingga menyebabkan mereka terus berkekalan di dalam kekufuran dan tidak beriman. Kerana itu dapat dirumuskan bahawa apa yang dikehendaki oleh Allah melalui ungkapan "tadabbür" di sini ialah renungan, tafakur dan penelitian yang mendalam dan halus terhadap apa yang tersurat dan juga apa yang tersirat dari ayat-ayat al-Quran, iaitu melalui instrumen akal dan minda yang sihat, dan pada masa yang sama, disokong dan didukung oleh jiwa dan hati yang bersih dan suci, bukannya jiwa dan hati yang terkunci dan tertutup, iaitu keadaan jiwa yang telah dicemari dengan elemen-elemen dosa, kekufuran dan keingkaran terhadap Allah.

Menurut mereka, ungkapan iqfäl al-qulüb, yang disebut oleh Allah di dalam ayat 24 surah Muhammad [maksudnya] "... atau hatihati mereka terkunci" merujuk kepada unsur-unsur "kekaratan" yang menimpa hati manusia sebagai natijah daripada pelbagai dosa yang dilakukan, sikap menuruti hawa nafsu dan syahwat tanpa pertimbangan yang wajar, perasaan cinta keterlaluan terhadap kehidupan dunia dan nikmatnya, sikap kelalaian yang berlebihan, cintakan kerehatan, pujian, sanjungan dan sifat-sifat lain yang tidak diredai Allah. Kerana itu bilamana Allah menyingkapkan

Ibid. 
serta membuka kembali "tutupan-tutupan" tersebut daripada hatihati berkenaan, ekoran daripada sifat taubat dan penyesalan yang benar yang dilakukan oleh seseorang, maka ini akan menyebabkan Tuhan, melalui rahmatNya, membuka semula kunci-kunci (al-aqfäl) yang menutupi hati tersebut sehingga menyebabkan hati-hati tersebut dilimpahi dengan pelbagai kefahaman yang tersirat mengenai pengertian al-Quran. ${ }^{6}$ Hakikat ini, menurut golongan ini, memperlihatkan bahawa sekiranya jiwa dan hati dapat dibersihkan dari pencemaran-pencemaran dosa dan kelalaian maka ianya akan menjadi faktor utama yang akan membuka ruang yang cukup luas bagi seseorang untuk menerokai serta menyelami maksud-maksud yang tersirat di dalam ayat-ayat al-Quran.

Menurut golongan ini juga, tidak ada satu ayat pun daripada ayat-ayat al-Quran melainkan ianya dapat difahami serta boleh ditafsirkan melalui empat sudut iaitu secara zāhir, bātin, hadd dan mațla'. Pengertian zăhir merujuk kepada pembacaan lafaz-lafaz al-Quran, pengertian bātin merujuk kepada kefahaman mengenai makna-makna al-Quran berasaskan kepada instrumen bahasa Arab dan melalui kaedah-kaedah ilmu usul tafsir, pengertian hadd merujuk kepada penjelasan mengenai apa yang halal dan apa yang haram di dalam sesuatu ayat al-Quran manakala pengertian mațla merujuk kepada keadaan hati yang telah tersingkap ekoran dari kesuciannya sehingga memungkinkannya memahami maknamakna yang tersirat mengenai al-Quran dan ini merupakan suatu anugerah dari sisi Allah. ${ }^{7}$

Di dalam mendokong kenyataan ini Abū Hâamid al-Ghazāli menyatakan bahawa di antara adab-adab utama membaca alQuran ialah berusaha melepaskan diri dari faktor-faktor yang boleh menghalang dan menghijab hati dari memahami rahsia dan pedoman yang tersirat di dalam ayat-ayat al-Quran. Beliau menyatakan, "... maka sesungguhnya ramai dari kalangan manusia yang telah terhalang dari memahami makna-makna al-Quran adalah disebabkan oleh "hijab-hijab" yang telah dilabuhkan oleh syaitan ke atas hati-hati mereka, maka akibatnya hati-hati mereka

\footnotetext{
$6 \quad$ Ibid., h. 211.

7 Ibid., h. 209.
} 
menjadi buta untuk melihat keajaiban-keajaiban rahsia al-Quran ...."

Begitu juga golongan ini berhujah berdasarkan suatu riwayat di mana bilamana 'Alì ibn Abi Țālib ditanya, "Apakah ada Nabi saw mengkhususkan kepada kamu dengan sesuatu pemberian [yang berkaitan dengan Islam yang lain dari wahyu al-Quran]? Lalu beliau menjawab, "Tidak, tiada di sisi kita selain dari apa yang termaktub di dalam helaian-helaian kertas ini [al-Quran] ataupun sesuatu kefahaman yang khusus tentang maksud dan pengertian kitab Allah yang seseorang itu diberikan [secara langsung dari sisi Allah]."

Menurut golongan ini, kefahaman yang dimaksudkan di dalam ucapan 'Ali ibn Abi Ṭālib ini merujuk kepada kefahaman tentang al-Quran yang disingkapkan oleh Allah kepada seseorang atas limpah kurniaNya.

Bagi golongan para ulama yang mengharuskan serta menerima pentafsiran al-Quran secara al-ishärah ini mereka telah meletakkan empat syarat utama yang wajib dipenuhi. Tujuannya adalah bagi mempastikan tafsiran-tafsiran yang dilakukan secara al-ishärah itu tidak tersasar atau jauh terseleweng dari jalan yang benar, iaitu dari kefahaman al-Quran yang didukung oleh para ulama ahli Sunnah wa al-Jamaah.

Empat syarat tersebut ialah:

1. Janganlah maksud yang terhasil melalui al-ishārah itu bercanggah, menyalahi dan menolak makna-makna yang zahir lagi jelas yang dapat difahami daripada ayat-ayat yang ditafsirkan itu;

2. Janganlah seseorang itu mendakwa bahwa tafsir secara al-ishārah itulah "satu-satunya pengertian, maksud dan tafsiran" yang dikehendaki oleh Allah, bukannya makna yang dapat difahami secara zahir atau melalui kaedahkaedah lain yang muktabar;

3. Janganlah tafsiran secara al-ishārah itu disanggahi oleh

8 Abū Ḥāmid al-Ghaẓāli (1990), Ihyyà' 'Ulūmiak al-Dīn. j. 1. Beirut: Dār al-Khayr, h. 376.

9 Khālid 'Abd al-Raḥmān al- 'Akk (1986), op.cit., h. 208. 
dalil syarak lain yang sah atau oleh dalil akal yang sahih; dan

4. Tafsiran secara al-ishārah tersebut sewajarnya disokong serta diperkukuhkan oleh dalil-dalil syarak yang lain.

\section{PEMAKAIAN TAFSIR SECARA $A L-I S Y A R A H ?$}

Menurut pandangan Khālid 'Abd al-Raḥmān, walau pun tafsiran secara al-ishārah adalah dianggap harus sekiranya empat syarat yang dinyatakan itu dapat dira'ikan dengan sebaik-baiknya, namun menerima pakai tafsiran-tafsiran al-ishārah ini bukanlah sesuatu yang wajib. Di dalam hal ini beliau menjelaskan, "Adalah amat penting diketahui bahawa adalah tidak wajib bagi seseorang Muslim untuk menerima pakai tafsiran al-Quran secara isyarat ini, sebagaimana inilah keadaannya dalam konteks mentafsir al-Quran secara akal dan ijtihad yang berasaskan kepada kaedah-kaedah dan prinsip-prinsip tertentu yang kukuh. Ini adalah kerana tafsirantafsiran yang tersingkap secara al-ishārah ini lebih merupakan rahsia-rahsia al-Quran yang disingkapkan ke dalam hati seorang mukmin yang saleh lagi berilmu. Maka pengetahuan yang bersifat rahsia tersebut mungkin akan terus disimpan oleh seseorang itu sebagai suatu pengetahuan yang istimewa antara dirinya dan Allah, dan mungkin juga dia akan mengkhabarkan pengetahuan tersebut kepada orang lain dengan tidak mewajibkan orang lain tersebut menerimanya"10

\section{KARYA-KARYA TAFSIR AL-QURAN SECARA $A L-I S H \bar{A} R A H$}

Antara karya-karya tafsir yang muktabar lagi tersohor di dalam dunia Islam, yang kerap merangkumkan unsur-unsur tafsir secara al-ishārah ini di samping mera ikan keempat-empat syarat utama, seperti yang dinyatakan di atas, termasuklah kitab:

1. Tafsir Gharā'ib al-Qur'ān Wa Raghà’ibal-Furqān karangan Niz̄ām al-Dịn al-Naysabūri;

2. Tafsir Rūh al-Ma 'ànì Fì Tafsìr al-Qur'ān al-'Azịim Wa al-

$10 \quad$ Ibid., h. 209. 
Sab 'i al-Mathānì karangan Muhammad al-Alūsī; dan

3. Tafsir al-Bahrr al-Madìd Fì Tafsìr al-Qur'ān al-Majīd karangan Abū al- 'Abbās Aḥmad Ibn 'Ajībah.

Pada hemat penulis apa yang menjadikan karya-karya di atas cukup istimewa ialah para pengarangnya telah mengambil pendekatan tafsir yang menggabungkan antara metode tafsir alzăhir dan metode tafsir al-bātin [pengertian secara al-ishārah]. Melalui pendekatan ini maka para pembaca sebenarnya telah didedahkan mengenai kepentingan "makna-makna yang tersurat" yang merupakan teras, asas dan dasar kepada ilmu tafsir al-Quran; manakala "makna-makna yang tersirat" itu hanyalah merupakan "pelengkap dan penyempurna" kepada pelbagai rahsia yang dapat digarap dari ayat-ayat Allah.

\section{RUANG LINGKUP TAFSIR SECARA $A L-I S H \bar{A} R A H$}

Penelitian yang menyeluruh terhadap beberapa karya tafsir muktabar yang merangkumkan unsur tafsir secara al-ishārah ini jelas memperlihatkan bahawa tafsiran secara al-ishärah ini amat terfokus dan tertumpu kepada aspek-aspek yang berkaitan dengan tazkiyah al-nafs, iaitu permasalahan penyucian dan pembinaan jiwa. Dengan bahasa lain, tafsir secara al-ishārah lebih menjurus kepada menyingkapkan makna-makna yang tersirat di dalam al-Quran secara yang dapat dihubungkaitkan dengan aspek pembinaan kerohanian, keimanan, pengasuhan jiwa, riyādah alnafs dan pembinaan maqam al-ihsan.

Ini bermakna pentafsiran secara al-ishārah ini lebih bertujuan untuk menggarap, menyelami dan meneroka unsur-unsur "tasawuf" dan aspek pendidikan akhlak di dalam setiap ayat alQuran. Kerana itu dapat dirumuskan bahawa pendekatan tafsiran secara al-ishārah ini tidak mempunyai peranan yang sebenar di dalam menyingkapkan hukum-hakam fiqh yang terdapat di dalam ayat-ayat hukum al-Quran.

Walau bagaimana pun perlu dijelaskan bahawa hakikat ini tidak bermakna ayat-ayat hukum di dalam al-Quran tidak mempunyai sebarang ruang untuk ditafsirkan secara al-ishārah atau diabaikan sebegitu sahaja oleh mereka yang cenderung untuk mengenengahkan pentafsiran secara isyarat ini. Malah apa menarik 
untuk dinyatakan di sini ialah ayat-ayat hukum yang terdapat di dalam al-Quran turut ditafsirkan oleh para ulama secara al-ishārah. Pada hemat penulis, inilah di antara keunikan dan kehebatan para ulama tafsir yang tersohor di mana mereka sentiasa berusaha dan mampu untuk mengenengahkan pengertian-pengertian al-Quran secara menyeluruh, yang tersurat dan yang tersirat.

Antara misalan yang dapat dikemukakan di sini mengenai bagaimana ayat hukum ditafsirkan secara al-ishārah:

1. Di dalam mengulas ayat yang mengharamkan seseorang Muslim memakan harta orang ramai secara batil atau melalui jalan salah, iaitu di dalam firman Allah di dalam ayat 188 surah al-Baqarah [maksudnya], "Dan janganlah kamu memakan harta-harta kamu di antara kamu secara batil dan salah...", Ibn 'Ajibah menyatakan, "Yang batil itu adalah segala sesuatu yang lain dari Allah. Maka sesiapa sahaja yang mengambil atau menerima sesuatu harta atau habuan daripada orang ramai dan tidak melihat Allah sebagai Zat sebenar yang memberi di dalam pemberian tersebut maka dia sebenarnya telah mengambil harta orang ramai secara batil...."11

2. Di dalam mengulas ayat yang berkaitan dengan hukum jihad dan peperangan, iaitu ayat 190 surah al-Baqarah yang bermaksud, "Dan perangilah - pada jalan Allah - orangorang yang memerangi kamu dan janganlah melampaui batas...", Ibn "Ajībah menyatakan, "Ketahuilah bahawa musuh-musuh bagi seorang hamba yang akan menghalang dan memutuskan dirinya dari hadrat Allah ada empat: hawa nafsu, syaitan, dunia dan manusia. Maka memerangi hawa nafsu ialah dengan menyalahi keinginan dan dorongannya dan membebankan nafsu dengan melakukan apa yang tidak disukai sehingga nafsu itu akan terasuh dan terdidik. Memerangi syaitan ialah dengan tidak tunduk kepada perintah dan arahan-arahannya. Memerangi dunia ialah dengan bersikap zuhud dari nikmat-nikmat dunia dan sentiasa reda dan berpuas hati dengan apa yang tersedia

11 Abū al-'Abbās Aḥmad Ibn 'Ajībah (2002), al-Baḥr al-Madīd fī Tafsìr al-Qur' ān al-Majīd, j. 1. Beirut: Dār al-Kutub al- 'Ilmiyyah, h. 191. 
[tidak tamak] manakala memerangi manusia ialah dengan mengosongkan tumpuan hati terhadap mereka dan berpaling dari mereka ...."12

3. Di dalam mengulas ayat yang berkaitan dengan keharusan mencari "rezeki tambahan" dan berniaga dalam tempoh ibadat haji, iaitu ayat 198 surah al-Baqarah yang bermaksud, "Tidaklah menjadi dosa atau kesalahan kepada kamu untuk mencari limpah kurniaan Tuhan kamu [ketika melakukan ibadat haji]...." Ibn 'Ajibah menyatakan, "Seseorang hamba itu - tidak boleh tidak - perlu terus mencari penambahan kurniaan Tuhan, walau pun dia telah berjaya sampai ke puncak kesempurnaan. Maka merasa cukup dan puas dalam pendakiannya menuju Allah merupakan suatu hirmān [suatu keadaan yang menyebabkan pelbagai anugerah Allah terlepas dari dirinya], dan beriktiqad bahawa dirinya telah sampai ke penghujung pendakian merupakan suatu kekurangan. Maka bukanlah suatu kesalahan, wahai para ahli ma'rifah, untuk kamu terus mencari kurniaan Tuhan kamu dengan tujuan untuk menambahkan lagi keyakinan dan keimanan kamu [terhadap Tuhan]...."13

4. Di dalam mengulas ayat yang berkaitan dengan persoalan darah haid, iaitu ayat 222 surah al-Baqarah yang bermaksud, "Dan mereka bertanya kepada engkau perihal hukum haid, katakanlah darah haid itu adalah sesuatu yang boleh mendatangkan mudarat..." Ibn 'Ajïbah menyatakan, "yakni, apabila kamu, wahai para 'àrifìn, ditanya mengenai nafsu, iaitu pada ketika ianya berjunub dengan kelalaian dan najis menyintai dunia maka katakanlah ianya [nafsu yang seperti ini keadaannya] adalah kotor dan bernajis, maka barang siapa yang menghampirinya nescaya dia akan turut dikotori dengan najis nafsu tersebut; justeru tidak halal untuk mendampingi seseorang yang nafsunya masih kotor sehinggalah orang tersebut disucikan dari janabah kelalaian dan dari kekotoran najis menyintai dunia...."

Di sini kita dapat melihat bagaimana Ibn 'Ajībah mengertikan darah haid yang kotor, dari segi tafsiran tersiratnya, sebagai merujuk

\footnotetext{
12 Ibid., j. 1, h. 195.

$13 \quad$ Ibid., j. 1, h. 201.
} 
kepada "hawa nafsu yang masih kotor dan tercemar dengan sebab kelalaiannya dan menyintai dunia". Justeru, hawa nafsu yang masih kotor seperti ini tidak wajar didekati kerana ditakuti kekotorannya akan tercalit kepada sesiapa yang mendekatinya. ${ }^{14}$

\section{CONTOH TAFSIR AYAT AL-QUR'ĀN SECARA ISYARAT}

Di sini penulis ingin mengemukakan beberapa contoh lagi tafsiran al-Quran secara al-ishārah bagi memperlihatkan bagaimana alQuran telah difahami serta diulas melalui pendekatan ini.

1. Di dalam mentafsir ungkapan Allah yang bermaksud, "...Dan mereka yang bermujahadah pada Kami, nescaya Kami akan menunjuki mereka jalan-jalan Kami."

Surah al-'Ankabūt (29): 69

Ibn 'Ajībah menyatakan, “...maka al-mushāhadah [penyaksian mata hati terhadap Allah dan segala sifatsifatNya] adalah menurut kadar mujahadah. Justeru, barangsiapa yang tidak bermujahadah maka dia tidak akan mencapai mushāhadah. Maka dengan kriteria mujahadah inilah golongan-golongan yang khusus berbeza dan dibezakan daripada orang-orang Islam awam. Dan begitu juga dengan perlaksanaan mujahadah inilah terhasillah perjalanan kerohanian mereka yang sedang bermusafir menuju Allah. Maka orang-orang Islam yang "awam" sentiasa tertakluk untuk memenuhi keinginan-keinginan hawa nafsu mereka, yang berkaitan dengan pangkat, kekayaan dan sebagainya, sedangkan golongan yang "khusus" sentiasa berusaha menyalahi dorongan-dorongan hawa nafsu mereka dan memecahkan adat-adat kebiasaan mereka sehingga akhirnya tercariklah segala adat untuk mereka [yakni, berlakunya perkara-perkara yang mencarik adat] dan tersingkaplah dari mereka segala hijab sehingga

$14 \quad$ Ibid., j. 1, h. 223. 
mereka dapat menyaksikan "Zat yang dicintai" [Allah Taala]...."15

2. Di dalam mengulas firman Allah yang bermaksud,

"Dan demi sesungguhnya Kami telah mencipta tujuh jalan di atas kamu dan Kami pula tidak lalai dari makhluk-makhluk ciptaan Kami."

Surah al-Mu'minūn (23): 17

Menurut para ulama tafsir, tujuh jalan yang dimaksudkan di dalam ayat di atas merujuk kepada tujuh petala langit yang dicipta Allah. ${ }^{16}$ Walau bagaimana pun, ketika memberikan unsur tafsir bi al-ishārah, Ibn 'Ajïbah menyatakan, “....yakni, Kami [Allah] telah mencipta tujuh hijab [tujuh tutupan] di atas hati-hati kamu, maka barang siapa yang berjaya merentasinya nescaya dia akan terpimpin untuk menyaksikan zat Kami dan cahaya-cahaya sifat-sifat Kami, di mana hijab yang dimaksudkan di sini ialah hijab dosa dan maksiat, hijab kekurangan dan keaiban diri, hijab kelalaian, hijab adat-adat kebiasaan dan nafsu syahwat, ...maka barang siapa yang berjaya merentasi hijab-hijab tersebut dengan bertaubat, melakukan proses tazkiyah al-nafs, kesedaran jiwa, 'iffah [tidak melakukan sesuatu kerana nafsu semata-mata], melakukan latihan mengekang nafsu, bermesra dengan Allah dan menjadi fana' dari segala yang lain dari Allah nescaya akan terangkatlah hijab-hijab tersebut dari hatinya dan dia akan sampai kepada Zat yang dicintai...."17

3. Di dalam mengulas firman Allah yang bermaksud, "Dan tidakkah mereka melihat bahawa Kami telah menjadikan tanah suci yang dihormati lagi aman ini."

Surah al-'Ankabūt (29): 67

Ibid., j. 5, h. 328.

16 Muhammad 'Alì al-Ṣābūni (2000), Șafwah al-Tafâsìr. j. 2. Beirut:

Dār al-Turāth al- 'Arabī, h. 209.

17 Abū al-'Abbās Ibn 'Ajībah (2002), op.cit., j. 5, h. 10. 
Para ulama tafsir menyatakan bahawa tanah suci yang dihormati lagi aman di sini merujuk kepada tanah haram Mekah. ${ }^{18}$ Walau bagaimana pun ketika mengemukakan unsur tafsir bi al-ishārah mengenai ayat ini Ibn 'Ajibah menyatakan, "Tanah suci yang dihormati lagi aman di dalam kehidupan dunia ini ialah al-tabattul, iaitu menumpahkan seluruh tumpuan kepada pengabdian diri kepada Allah dan memutuskan diri dari dunia [yang tercela] dan dari mereka yang menjadi hamba kepada dunia, maka barangsiapa yang memasuki al-ḥarām yang dinyatakan ini nescaya dia akan mengecapi keamanan zahir dan batin, ...."19

4. Di dalam mengulas ayat al-Quran yang bermaksud,

"Dan apabila manusia ditimpa dengan sesuatu kemudaratan maka mereka akan berdoa kepada Tuhan mereka dalam keadaan kembali kepadaNya, dan kemudiannya apabila Tuhan merasakan mereka dengan sesuatu rahmat dari sisiNya, tiba-tiba suatu kelompok dari kalangan mereka mempersekutukan Tuhan mereka."

\section{Surah al-Rūm (30): 33}

Ibn 'Ajïbah menyatakan, “... adalah wajib bagi para mukminin untuk berakhlak dengan akhlak yang berlawanan dan berbeza daripada akhlak golongan yang kafir, maka apabila mereka ditimpa dengan sesuatu kemudaratan atau kesusahan maka mereka hendaklah, samada bersegera bertawajjuh kepada Allah dengan penuh khusyuk sambil menghinakan diri dan memohon kepada Allah dan menantikan apa yang Allah akan lakukan terhadap mereka, atau terus bersabar, bersikap reda di dalam menghadapi segala takdir Allah yang berlaku pada mereka. Dan begitu juga bilamana mereka mendapat nikmat atau terlepas dari sesuatu musibah dunia, mereka hendaklah bersyukur kepada Allah, memujiNya dan menyandarkan segala pelepasan

18 Muhammad 'Alī al-Sābūni (2000), op.cit., j. 2, h. 319; Muhammad bin 'Umar al-Jāwì (1997), Marāh Labìd, j. 2. Beirut: Dār al-Kutub al-'Ilmiyyah, h. 222.

19 Ibn 'Ajibah (2002), op.cit., j. 5, h. 327. 
yang berlaku itu kepada zat Allah semata-mata. Dan begitu juga sekiranya berlaku dari mereka sesuatu usaha dan ikhtiar yang diperakui syarak, maka mereka janganlah memandang kepada ikhtiar dan usaha yang mereka lakukan itu, kerana pada hakikatnya - tidak wujud sebarang "kesan sebenar" di sebalik ikhtiar yang dilakukan itu. Malah segala pelepasan itu adalah dari Allah semata-mata, maka janganlah dia berkata "ini adalah kerana sebab dan usaha si fulan dan si fulan". Sebaliknya, Zat yang sebenarnya melakukan semua itu adalah Allah yang Maha Esa...."20

5. Di dalam mengulas firman Allah yang bermaksud,

"Dan berapa banyak binatang yang tidak membawa rezekinya bersama, Allah jualah yang memberi rezeki kepadanya dan kepada kamu...."

Surah al-'Ankabūt (29): 60

Ibn 'Ajibah menyatakan, "Rezeki adalah sesuatu yang telah dijamin di tangan Zat [Allah] yang urusanNya adalah di antara $K \bar{a} f$ dan Nun, ianya tidak akan bertambah dengan sifat tamak dan haloba golongan-golongan yang kuat dan berkuasa, dan tidak juga menjadi kurang dengan sebab kelemahan orang-orang yang lemah, bahkan kadang kala sebaliknya yang berlaku...."21

\section{PENILAIAN DAN RUMUSAN}

Berasaskan kepada penjelasan yang serba ringkas di dalam penulisan ini, penulis ingin menyatakan beberapa rumusan penting yang berkaitan dengan pendekatan tafsir secara al-isyarah ini iaitu:

1. Walau pun terdapat segelintir para ulama yang tidak begitu bersetuju dengan metode tafsir secara al-ishārah sebagai salah satu daripada metode pentafsiran al-Quran yang muktabar dan sahih dengan anggapan pelbagai kesilapan dan pemesongan makna boleh berlaku, namun segala pemesongan dan penyelewengan tafsir tersebut pastinya

\footnotetext{
20 Ibid.

${ }^{21} \quad$ Ibid., j. 5, h. 324.
} 
dapat dielakkan sekiranya segala syarat tafsir yang telah ditentukan oleh para ulama dapat dira ikan dengan sebaikbaiknya.

2. Dari sudut perkembangan ilmu tafsir adalah jelas bahawa pentafsiran al-Quran secara al-ishärah telah pun mendapat kedudukan yang sewajarnya dalam kalangan para ahli tafsir. Ini dapat dilihat dengan jelas melalui kelahiran beberapa karya tafsir yang cukup muktabar dan ditulis pula oleh ulama yang muktabar yang turut merangkumkan aspek-asepk alishārah di dalam penulisan mereka. Secara kenyataannya karya-karya tafsir tersebut terus mendapat kedudukan dalam kalangan para ilmuan Islam dan tersenarai dalam kategori karya-karya besar tafsir sehingga hari ini. Hakikat yang berlaku ini secara tidak langsung memperakui ketinggian nilai ilmu tafsir yang wujud di dalam karya-karya tersebut dan tidak menafikan sumbangan tafsir secara al-ishärah dalam aspek ilmu tafsir.

3. Berbalik kepada pendapat al-Nasafi di atas yang menyatakan bahawa "berpaling dari makna-makna yang zahir al-Quran kepada makna-makna yang tersirat" boleh membawa kepada kekufuran dan murtad, apa yang beliau maksudkan, menurut penelitian penulis, ialah apabila seseorang itu berpegang secara mutlak dengan tafsiran-tafsiran al-Quran secara al-ishārah dan mengingkari serta menolak pengertian al-Quran yang bersifat zahir dan tersurat di mana sikap seperti ini sudah semestinya akan membawa seseorang kepada kekufuran dan murtad. Kerana itu perlu dijelaskan bahawa bilamana segelintir para ulama mengharuskan pentafsiran secara al-ishārah ini mereka hanya menjadikan tafsiran tersebut sebagai pelengkap dan penyempurna kepada maksud dan rahsia yang dapat digarap dari ayatayat al-Quran dan mereka tidak sekali-kali mengingkari makna-makna al-Quran yang tersurat; malah pengertianpengertian yang tersurat itulah merupakan asas, teras dan tonggak kepada ilmu tafsir al-Quran.

4. Pendekatan tafsir secara al-ishārah yang memberikan fokus dan tumpuan utama terhadap perbincangan-perbincangan yang berkaitan dengan pembinaan jiwa dan tazkiyah al-nafs 
telah memberikan nilai yang tinggi terhadap ilmu tafsir itu sendiri. Ini adalah kerana aspek tazkiyah al-nafs itu sendiri merupakan matlamat terakhir di sebalik penurunan alQuran, sebagaimana yang dapat difahami melalui firman Allah yang bermaksud:

"Wahai Tuhan kami, utuskanlah kepada mereka seorang Rasul dari kalangan mereka yang akan membacakan kepada mereka ayat-ayat $M u$, mengajarkan mereka kitab Mu dan al-hikmah, dan yang akan membersihkan jiwa dan hati mereka"

\section{Surah al-Baqarah (2): 129}

5. Walau pun terdapat segolongan para ulama yang mendukung keharusan mentafsirkan al-Quran secara al-ishārah ini, namun keharusan ini masih terikat dengan kaedah dan prinsip umum ilmu usul tafsir dan juga syarat-syarat khusus yang berkaitan dengan tafsir al-ishārah itu sendiri. Dengan wujudnya kaedah-kaedah tersebut maka keutuhan nilai tafsir secara al-ishārah ini akan terus terpelihara dan unsur-unsur penyelewengan pentafsiran al-Quran, seperti yang ditakuti oleh segelintir para ulama, akan dapat dihindarkan.

6. Dari sudut tuntutan menghayati al-'ubüdiyyah lillāh dalam kehidupan sebagai seorang Muslim, pada hemat penulis, khazanah-khazanah karya tafsir yang merangkumkan unsur-unsur tafsīr bi al-ishärah, seperti karya-karya yang disenaraikan di atas, telah berjaya memberikan suatu sumbangan yang besar lagi bermakna. Ini adalah kerana tafsiran-tafsiran tersebut mempunyai kaitan yang langsung dengan persoalan pembinaan keimanan dan pendakian seseorang Muslim bagi mencapai maqam al-iḥsān. Kerana itu tafsiran-tafsiran al-Quran secara al-ishärah yang sahih dan menepati prinsip-prinsip usul tafsir amat wajar sekali dipelajari, dikaji, dan disebarkan ke tengah masyarakat. Semoga karya-karya tafsir bernilai tersebut akan dapat menyumbangkan suatu "ilmu yang bermanfaat" kepada umat Islam pada hari ini, iaitu tafsiran-tafsiran yang "tersirat" mengenai al-Quran yang tidak terkeluar dari rangkaian disiplin ilmu tafsir yang sah dan diperakui. 
Pada hemat penulis, tafsiran-tafsiran secara al-ishārah, seperti beberapa contoh yang dikemukakan oleh Ibn 'Ajibah di atas, memiliki nilai-nilai ilmu yang terlalu suci, yang sekiranya dihayati dan diamalkan dengan penuh ketulusan jiwa pastinya akan melonjakkan seseorang ke hadrat Allah Taala.

Walau bagaimana pun, menurut pemerhatian penulis, tafsir al-ishārah ini ada ketikanya melibatkan penggunaan rangkaikata atau istilah-istilah yang cukup teknikal, yang ada ketikanya sukar difahami hatta oleh para ilmuan Islam yang kurang mendapat pendedahan mengenai pengertian istilah-istilah tersebut menurut neraca ilmu tasawuf. Kerana itu, menurut penulis, dalam hubungan ini, panduan, bimbingan dan tunjuk ajar dari para ulama rabbani yang berwibawa dan berautoriti mengenai disiplin ilmu tasawuf amatlah diperlukan. Walau bagaimana pun kenyataan penulis di sini tidaklah membawa maksud bahawa karya-karya tafsir al-ishārah yang sedia wujud itu merupakan karya-karya yang terlalu komplikated dan rumit untuk difahami sehingga perlu dipinggirkan.

Apa yang ingin penulis tekankan bahawa bagi setiap disiplin ilmu itu ada ahli dan pakarnya yang berwibawa, dan unsur-unsur tafsir secara al-ishārah yang dapat ditatapi di dalam karya-karya tafsir tersohor ulama Islam merupakan khazanah ilmu tafsir bernilai yang wajar dikaji dan dipelajari, dan seandainya kita berhadapan dengan sebarang kekeliruan maka kita perlu merujuk kepada para ulama yang berautoriti yang sentiasa wujud di sekeliling kita sebagai suatu limpahan kurniaan Allah yang tiada batasnya.

Semoga Allah membimbing kita ke jalan yang diredaiNya. 